\title{
PENDAMPINGAN PERENCANAAN KAWASAN DESA WISATA JAYAN SENTING SAMBI BOYOLALI
}

\section{Dhani Mutiari ${ }^{1^{*}}$, Johan Maulana Muhammad ${ }^{2}$, Reyhan Raditya $S^{3}$}

Program Studi Arsitektur Fakultas Teknik Universitas Muhammadiyah Surakarta

${ }^{1}$ dhani.mutiari@ums.ac.id

2Johanmmtriyono98@gmail.com

32Reyhanglory@gmail.com

*correspoinding author

\begin{abstract}
ABSTRAK
Dusun Jayan terletak di Desa Senting Kecamatan Sambi Kabupaten Boyolali. Dusun ini berada di pinggir Waduk Cengklik dan posisinya tidak jauh dari Bandara Adi Soemarmo. Posisi geografi ini menjadikan Dusun Jayan memiliki potensi alam seperti pemandangan waduk yang menarik dengan potensi ikannya, persawahan dan peternakan. Selain potensi alam juga potensi arsitektur dengan rumah-rumah tradisional yang masih dipertahankan sampai sekarang, dan juga beberapa home industri. Salah satunya adalah rumah tradisional yang pemiliknya memproduksi kerajinan dari kayu.

Lima tahun terakhir potensi ini telah dilihat oleh IMM Fakultas Psikologi UMS dan mereka melakukan pendampingan yang berhubungan dengan potensi pemberdayaan masyarakat. Salah satu dari hasil pendampingannya adalah terbentuknya panggon sinau yang merupakan tempat taman bacaan bagi anak-anak. Selain itu juga beberapa kali diadakan festival yang bertujuan untuk menggerakkan masyarakatnya. Walaupun telah dilakukan pendampingan, tetapi menurut salah satu tokoh masyarakat disana kegiatan-kegiatan tersebut belum mampu untuk mengembangkan potensi yang ada di Dusun Jayan. Tahun 2017 mahasiswa Studio Perancangan Arsitektur 6 telah melakukan kunjungan dan berupaya untuk melakukan langkah awal dalam perencanaan kawasan wisata tetapi berhenti pada pengumpulan tugas.

Pada tahun 2020 ini kembali dengan program dan mahasiswa yang berbeda Mata Kuliah Studio Perancangan Arsitektur 6 kembali ke Dusun Jayan melakukan pengabdian masyarakat dengan tujuan untuk lebih dekat tidak hanya sekedar mengerjakan tugas mata kuliah tetapi berperan sebagai arsitek komunitas yang mendampingi perencanaan kawasan wisata sesuai bidang Ilmu Arsitektur. Kegiatan ini dimulai dengan pertemuan dengan tokoh masyarakat dan dilanjutkan dengan survey lapangan untuk menginventarisasi potensi. Kegiatan ini menghasilkan inventarisasi potensipotensi untuk mengembangkan kawasan wisata, master plan dan beberapa alternatif perencanaan kawasan prioritas untuk pengembangan wisata. Karya ini kemudian di presentasikan dan disosialisasikan di hadapan pemangku jabatan beserta tokoh-tokoh masyarakat yang ada disana.
\end{abstract}

KATA KUNCI: desa wisata, Jayan, pendampingan identitas Jayan, beberapa home industri seperti budi daya lele dan produksi peralatan dari bahan kayu.

Selama ini masyarakat disana telah memanfaatkan air waduk untuk mencari ikan dalam bentuk keramba- keramba, tetapi pemanfaatan ikan hanya dijual mentah dengan harga murah dan tempat pemancingan bagi masyarakat setempat. Lima tahun terakhir terdampat pendampingan dari IMM fakultas Psikologi UMS dalam pemberdayaan masyarakat terutama untuk anak-anak berupa taman bacaan dan juga bantuan dari lazis MU untuk perbaikan ruang wudlu dan kamar mandi di masjid 
Dukungan pemerintah daerah yaitu Kalurahan Senting belum cukup untuk menggerakkan masyarakatnya untuk lebih berdaya dalam mengembangkan perekonomian. Upaya untuk mengembangkan Dusun Jayan sebagai desa wisata telah beberapa kali dilakukan dengan terdapatnya festival-festival budaya di Waduk Cengklik, karena sifatnya hanya event tertentu sehingga sampai sekarang belum mengalami kemajuan yang cukup siknifikan.

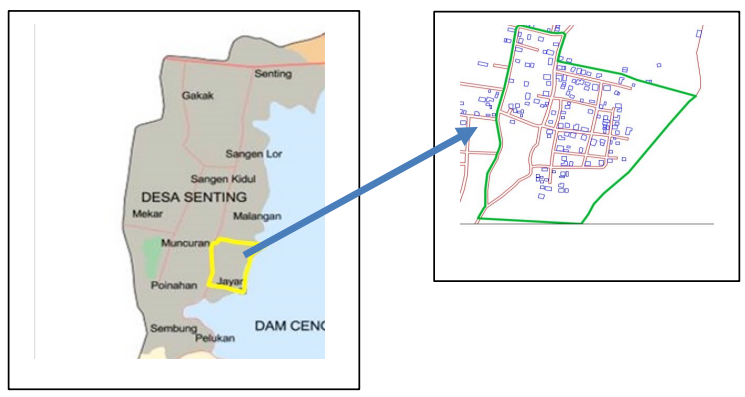

Gambar 1 :

Peta Lokasi Dusun Jayen Senting Sambi Boyolali Sumber : Kalurahan Senting Sambi Boyolali, 2017

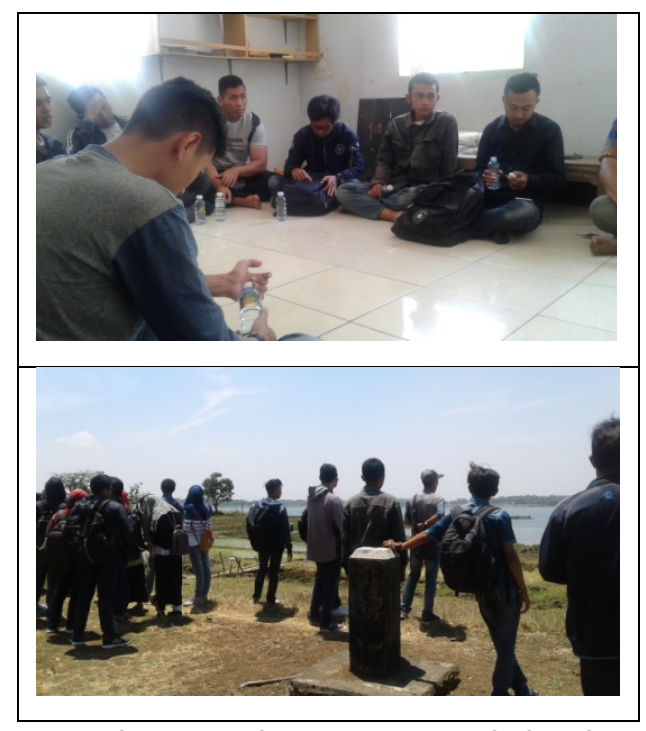

Gambar 2. Pendampingan IMM Al Ghazal

FakultasPsikologi UMS, Sumber: Dokumentasi, 2017

Pada tahun 2017 mahasiswa klas Studio Perancangan Arsitektur 6 mengadakan studi lapangan di sana untuk mencoba membuat desain kawasan wisata, tetapi hanya berhenti untuk pengumpulan tugas seperti terlihat pada gambar 2 . Tahun 2020 untuk mata kuliah yang sama mahasiswa klas Studio Perancangan Arsitektur 6 kembali melakukan kunjungan ke Dusun Jayan tujuannya bukan hanya sekedar mengerjakan tugas tetapi lebih ke dalam, yaitu berpraktek menjadi arsitek komunitas. Mereka melakukan survey, berhubungan dengan masyarakat, melakukan pendampingan dan mensosialisasikan karyanya kepada masyarakat (gambar 3)

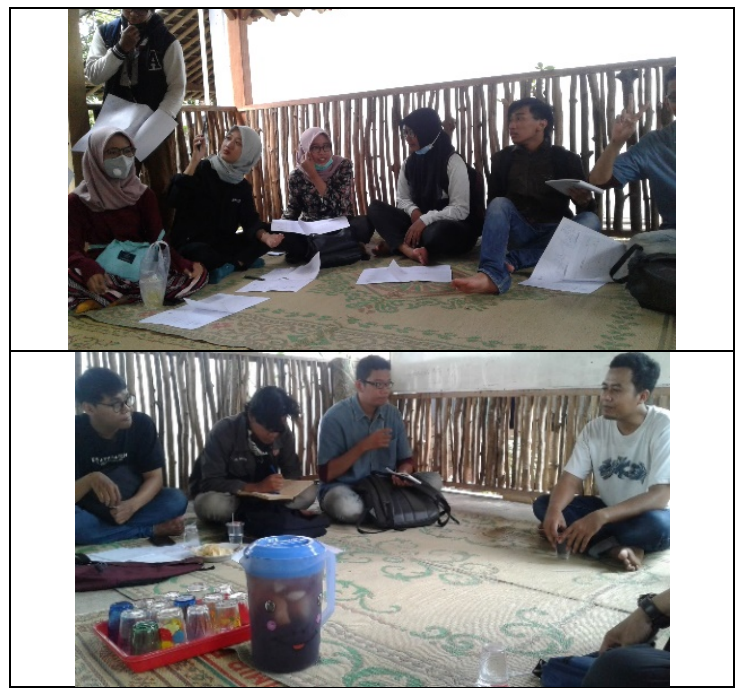

Gambar 3: Pertemuan dengan masyarakat Jayan Sumber dokumentasi 2020

Luas Dusun Jayan kurang lebih 24 ha berada di tepi Waduk Cengklik. Selain itu letak Dusun Jayan tidak jauh dari Bandara Adi Soemarmo (gambar 1). Keberadaan Waduk Cengklik menjadikan desa ini memiliki potensi alam seperti pemandangan nan indah, produksi ikan dan persawahan. Selain potensi alam juga terdapat potensi budaya serta pemberdayaan masyarakat seperti rumah-rumah tradisional, beberapa home indutri yang mengolah kayu serta peternakan. Lima tahun terakhir sebenarnya Dusun Jayan ini telah didampingi oleh IMM (Ikatan Mahasiswa Muhammadiyah) Fakultas Psikologi UMS dan telah menghasilkan sarana membaca bagi anak-anak yang disebut Panggon Sinau, tetapi untuk menjadikan dusun ini sebagai tujuan wisata masih sangat jauh. Dengan potensi yang ada ini masyarakat disana belum dapat memanfaatkannya dengan maksimal, permasalahannya adalah: Bagaimanakah mengembangkan Dusun Jayan menjadi desa wisata sehingga dapat mengembangkan perekonomian masyarakatnya?

Kampung atau Desa Wisata menurut [2] adalah sebuah kawasan yang aktivitas pariwisatanya memiliki keterkaitan yang kuat dengan kehidupan sehari-hari dalam masyarakat. Untuk memenuhi kebutuhan dan pelayanan tersebut, daerah tujuan wisata harus memiliki empat aspek pokok atau dikenal dengan istilah " $4 \mathrm{~A}$ " meliputi: (1) attraction; (2) accessibility; (3) amenities; dan (4) ancillary services. Desa Wisata juga merupakan kelompok 
swadaya dan swakarsa masyarakat yang dalam aktivitas sosialnya berupaya untuk meningkatkan pemahaman kepariwisataan, mewadahi peran dan partisipasi masyarakat dalam pembangunan kepariwisataan di wilayahnya, meningkatkan nilai kepariwisataan serta memberdayakannya bagi kesejahteraan masyarakat.

Menurut OECD (Organisation for Economic Cooperation and Development) pada tahun 2005 kriteria yang penting dalam merancang sebuah hubungan yang positif antara turisme dan budaya adalah sebagai berikut: (1) Memiliki aktivitas budaya yang permanen dan rutin dilakukan, (2) Melibatkan penduduk lokal secara langsung, dan sebagai tambahannya dapat melibatkan wisatawan, (3) dan dapat mengasilkan produk dan/atau jasa yang diperlukan untuk keperluan wisatawan.

Menurut [1] Urban Planning memiliki pengertian kegiatan yang meng-alokasi-kan penggunaan tanah dan pendirian bangunan serta jaringan jalan dengan tujuan untuk mencapai keseimbangan antara kenyamanan, keindahan dan biaya. Penelitian [6] menjabarkan terkait tiga teori urban design dalam bukunya yang berjudul Finding Lost Space. Tiga teori yng dimaksud oleh penelitian tersebut adalah (1). Figure Ground, merupakan studi terkait hubungan antara bentuk terbangun (building mass) dan rung terbuka (open space) melalui kajian dua dimensional berupa solid-void, (2). Linkage, membahas keterkaitan antara suatu tempat dengan tempat yang lainnya dari berbagai aspek sebagai generator kota, dan (3) Place, keberadaan teori ini mengarah pada pemaknaan dari ruang perkotaan. Menurut [3], elemen rancang kota dikelompokkan ke dalam delapan kategori, yaitu: Tata Guna Lahan (Land Use), Bentuk Dan Massa Bangunan (Building Form and Massing), Sirkulasi dan Parkir (Circulation and Parking), Ruang Terbuka (Open Space), Area Pedestrian (Pedestrian Area), Tanda-tanda (Signage), Pendukung Kegiatan (Activity Support), dan Konservasi (Concervation). Teori yang diformulasikan oleh [4], didasarkan pada citra mental jumlah penduduk dari kota tersebut. Ada lima elemen kota yang mendasar yang mampu memberikan kualitas visual bagi kota itu sendiri. Elemen-elemen inilah yang dianggap kasat mata dan terasa di kawasan kota. Lima elemen kota ini adalah: Jalur (path), Tepian (edge), Kawasan (District), Simpul (Nodes) dan Tangeran (Landmark) [5].

\section{METODE}

Cara yang dilakukan untuk menyelesaikan masalah di Dusun Jayan adalah :

1. Melakukan Inventarisasi Potensi Wisata Dusun Jayan

2. Melakukan pendampingan perencanaan penataan Kawasan Desa Wisata di Dusun Jayan. Solusi yang ditawarkan adalah:

a. Penentuan Master Plan Dusun Jayan

b. Perencanaan Kawasan Prioritas sebagai area wisata awal

Kegiatan ini diharapkan kedepannya dapat dilanjutkan secara bertahap ke beberapa tempat menjadi area-area wisata sehingga secara keseluruhan Dusun Jayan akan menjadi Desa Wisata yang ter integrase.

\section{HASIL DAN ANALISA}

\section{Pelaksanaan}

Pengabdian Masyarakat yang bertemakan pendampingan Perencanaan Kawasan Desa Wisata Jayan Senting Sambi Boyolali dilakukan dalam 3 tahap, yaitu: inventarisasi potensi wisata, pembuatan master plan dan perencanaan kawasan prioritas. Lebih detilnya akan diuraikan lebih lanjut:

\section{a. Inventarisasi potensi wisata dan kemungkinan pengembangannya}

Pada awal pelaksanaan dilakukan pertemuan antara 15 mahasiswa Program Studi Arsitektur yang mengikuti mata kuliah Studio Perancangan Arsitektur 6 klas C di dampingi oleh dosen pembimbing dengan beberapa tokoh masyarakat Dusun Jayan Desa Senting dan IMM Fakultas Psikologi UMS yang telah sebelumnya aktif di dusun tersebut (gambar 4). Cara ini dilakukan selain untuk kula nuwun juga mencari informasi awal tentang gambaran umum Dusun Jayan.

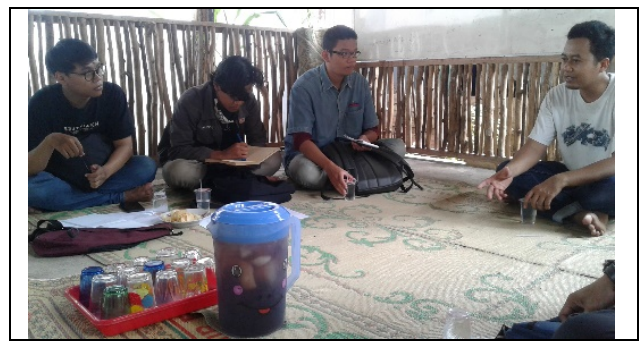




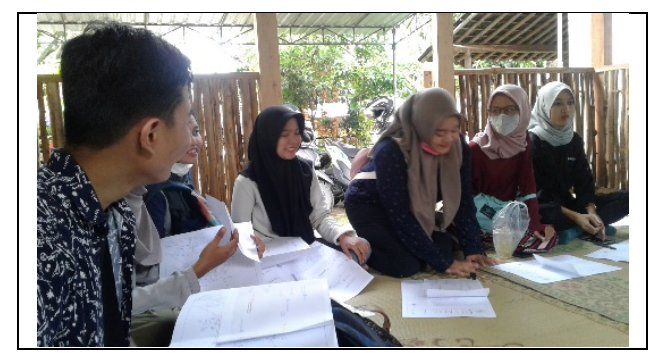

Gambar 4: Pertemuan awal antara mahasiswa dan tokoh masyarakat serta IMM Fakultas Psikologi UMS. Sumber: dokumen pribadi, 2020

Pertemuan ini kemudian dilanjutkan dengan survey lapangan yang dilakukan oleh mahasiswa didampingi salah seorang mahasiswa IMM, dengan harapan dapat dengan mudah keliling dusun dan bertemu dengan masyarakat setempat (Gambar 5).

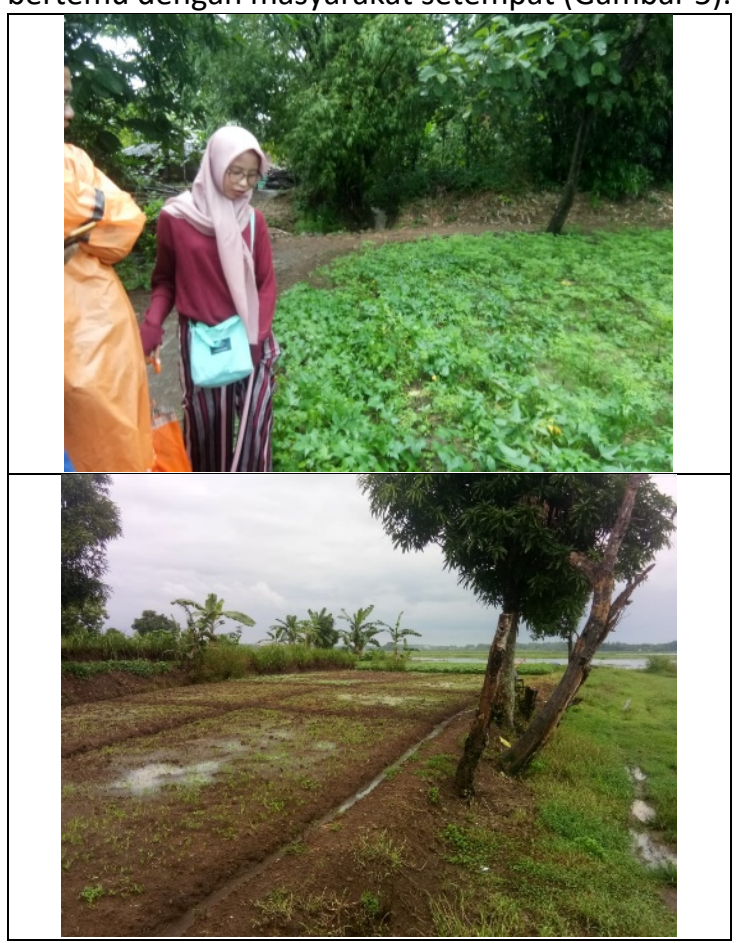

\section{Gambar 5: Pelaksanaaan Survey dan beberapa data tanaman Sumber: Dokumen pribadi, 2020}

Dari hasil pertemuan pertama dan survey lapangan serta wawancara kepada beberapa masyarakat maka terinventarisasi potensi-potensi yang dapat dikembangkan sebagai kawasan wisata. Potensi tersebut adalah:

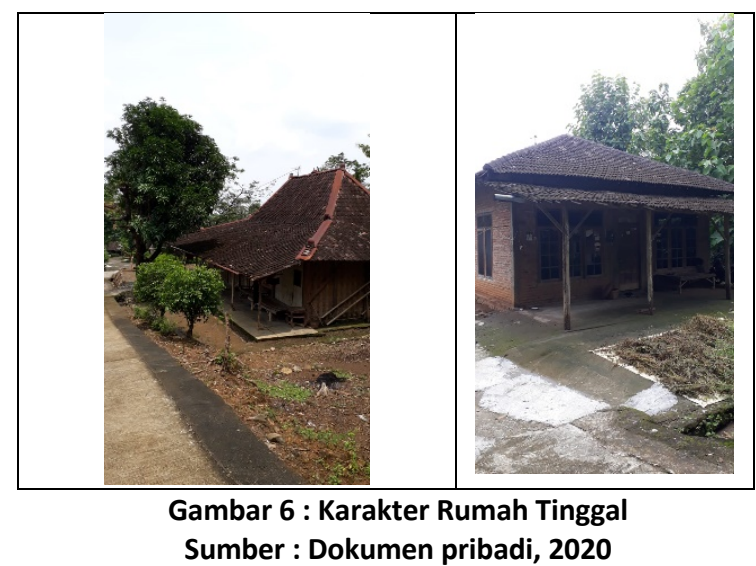

a.1. Potensi Alam

Dusun Jayan sebagai kasus dalam program pengabdian masyarakat ini terletak di Desa Senting, Kecamatan Sambi, Kabupaten Boyolali, Jawa Tengah. Secara geografi terletak sekitar 16 $\mathrm{km}$ dari ibukota Boyolali, dan berada sekitar $5 \mathrm{~km}$ dari Bandara Internasional Adi Soemarno ke arah barat. Lokasinya ini sangat strategis dan mudah untuk dijangkau. Memiliki tanah berkontur yang dimanfaatkan sebagai tanah pertanian dan tanaman sayuran lainnya. Selain itu Dusun Jayan juga memiliki potensi perairan Waduk Cengklik yang membatasi dusun ini dengan wilayah lain.

Pengembangan potensi alam yang dapat dilakukan adalah:

\section{a.1.1. Berdasarkan Lokasi}

Kedekatannya dengan lokasi startegis seperti Bandara Adi Sumarmo menjadi peluang untuk dipromosikan dengan cara membuat spanduk dan brosur desa wisata dengan menyertakan denah yang ditempatkan di tempat strategis untuk menarik wisatawan lokal ataupun luar negeri.

a.1.2. Berdasarkan Keadaan Alam

Dusun Jayan memiliki potensi untuk ditanami tanaman berdasarkan identifikasi tanah yang sudah diketahui sehingga tanaman dapat tumbuh subur ditempat tersebut. Mengembangkan dan mengolah tanaman setempat menjadi barang yang bernilai sehingga dapat meningkatkan perekonomian desa. Tanah yang berkontur dan lingkungan yang masih asri dapat dimanfaatkan untuk mengatur penggunaan kendaraan bermotor di daerah tersebut sehingga nantinya wisatawan yang berkunjung dapat berjalanjalan tanpa menggunakan kendaraan dan desa bebas dari polusi asap. Sedang untuk pemancingan difokuskan pada rekreasi ekonomi yaitu untuk meningkatkan nilai pariwisata dan nilai ekonomi, seperti menyewakan transportasi Perahu Getek, 
penjualan alat pancing bagi wisatawan, penjualan umpan untuk pancing ikan dan penjualan ikan hasil pancingan yang didapat.

\subsubsection{Berdasarkakan Sejarah, Sosial Budaya,} Potensi ini dapat dikembangkan wisata edukasi edukasi dengan Panggon Sinau sebagai sarana membaca untuk anak anak. Selain itu dapat juga mengembangkan wisata alam sebagai sarana edukasi berupa mengenalkan penanaman padi, membajak sawah, dan budidaya perikanan (di area waduk). Mengembangkan budidaya tehtehan dan bunga sebagai sarana edukasi dan selfi. Mengembangkan potensi waduk dengan kegiatan kegiatan permainan air seperti memancing sebagai sarana edukasi. Mengembangkan potensi rumah tradisional sehingga lebih terawat dan terjaga serta pengenalan terhadap wisatawan. Mengembangkan potensi desa jayan yang bersal dari kata kejayaan yang dilambangkan kuda sebagai simbol kejayaan.

\section{a.2. Industri dan Ekonomi}

Di Dusun Jayan ditemukan satu rumah tradisional penduduk yang digunakan untuk indutri kerajinan kayu jati, yang dapat dikembangkan menjadi indutri yang lebih baik dengan pendampingan desain. Selain itu juga terdapat pemancingan di pinggir danau cengklik dan ternak ikan di pemukiman masyarakat dekat dengan Danau Cengklik (Gambar 6 dan7)

Pengembangan yang dilakukan untuk industri kayu dengan cara: memberikan edukasi kepada warga mengenai kerajinan kayu baik untuk pengembengan furniture maupun cendramata khas setempat. Mengumpulkan warga yang tidak bekerja untuk membuat kerajinan kayu agar menciptakan ekonomi yang lebih baik. Memberikan edukasi kepada warga mengenai pemasaran produk yang baik dan benar (online maupun of line). Memanfaatkan semaksimal mungkin penggunaan kayu yang diarahkan untuk memberdayakan ekonomi masyarakat setempat dan kemungkinan kerja sama dengan pihak swasta.

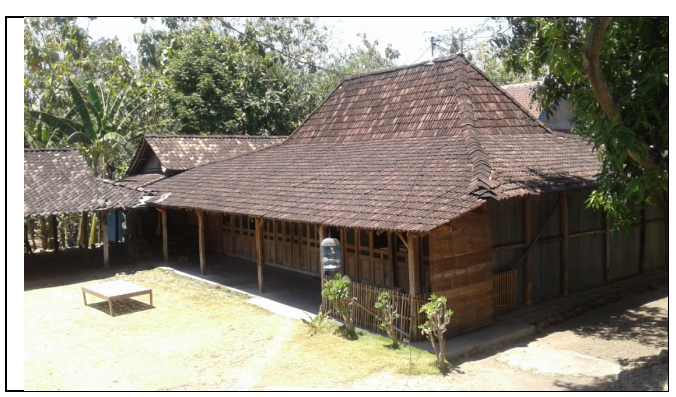

Gambar 7: Rumah tradisional sebagai home industri kerajianan kayu

Sumber : Dokumen pribadi, 2020

a.3. Sosial Budaya

Di Dusun Jayan terdapat beberapa organisasi masyarakat seperti Muhammadiyah, NU, LDII, Ibu-ibu PKK, Karang Taruna, Paguyuban Bapak-bapak dan Perkemuja. Selain itu juga terdapat kegiatan budaya yang sudah routin dilakukan seperti: bersih desa, kerja bakti, bantuan desa, mancing, ternak lele, ayam, sapi, kambing, iuran per triwulan dan pengajian keliling.

\section{a.4. Organisasi dan Partisipasi Masyarakat}

Secara organisasi Dusun Jayan telah memiliki perangkat desa seperti BPD dan TPK yang dapat bekerja sama dengan pemerintah desa dan organisasi masyarat di dalam mengembangkan Dusun Jayan sebagai kawasan wisata. Organisasi masyarakat ini dapat digerakkan untuk mengembangkan kuliner dan komunity garden, serta hal-hal lain yang dapat mengembangkan perekonomian di sana.

a.5. Organisasi dan pelaksanaan pembangunan

Program pembangunan daerah yang selama ini telah terlaksana ada 2 sektor yaitu pemerintah daerah yang diwakuli oleh BPD (Badan Permusyawaratan Desa) dan sektor kepengurusan daerah. Kedua sektor pelaksanaan pembangunan ini dapat bekerja sama selaku eksekutif dan legislatif. Sehingga pelaksanaannya dapat terkontrol.

a.6. Pendanaan, pentahapan dan strategi implementasi

Selama ini pendanaan cukup lancar dan digunakan untuk betonisasi jalan dan pembangunan posyandu. Untuk lebih kedepannya dapat polusi. Lahan yang dapat ditanami tanaman dapat dikembangkan lagi serta lahan yang sulit dikembangkan dapat dibuat bangunan untuk menunjang desa wisata tersebut seperti restoran, tempat belajar 
budaya atau yang lainnya. Waduk yang menjadi ikon utama dapat dimanfaatkan sebagai tempat pemancingan, spot foto, atau spot wisata yang menarik lainnya

\section{DISKUSI / PEMBAHASAN,}

a. Master Plan Desa Wisata di Dusun Jayan

Dari inventarisasi potensi dan pengembangnnya dibuatlah master plan sebagai berikut:

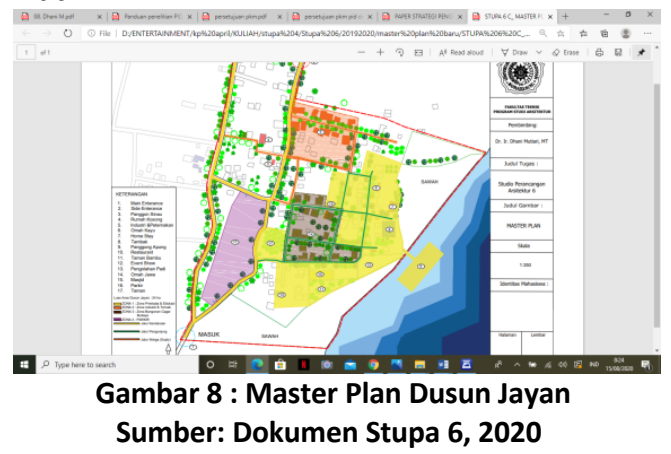

b.1. Zonifikasi

Di dalam master plan ini Dusun Jayan terbagi menjadi 4 zona terdiri atas : (Gambar 8)

Zona 1: zona priwisata \& edukasi

Zona 2: zona industri \& ternak

Zona 3: zona bangunan cagar budaya

Zona 4: parkir

\section{b.2. Acesibilitas/ Pencapaian}

Pencapaian kedusun ini melalui 2 jalur main entrance melalui jalur selatan dan side entrance dapat dicapai dari arah utara

\section{b.3. Sirkulasi}

Sirkulasi terbagi menjadi 3 yaitu :

(1) jalur kendaraan

(2) jalur pengunjung

(3) jalur warga (suply)

Dengan adanya pemisahan jalur ini diharapkan ke depannya dusun wisata ini lebih teratur dan pengunjung lebih nyaman untuk sampai ke tempat wisatanya.

c. Perencanaan area prioritas sebagai kawasan wisata.

Terdapat beberapa penyelesaian desain pada kawasan prioritas tetapi di dalam aplikasinya terdapat konsep yang cenderung diminati oleh masyarakat setempat yaitu perubahan yang tidak terlalu besar dengan keadaan semula, yaitu kontekstual terhadap kawasan dan konservasi dari bangunan-bangunan yang ada disana.(Gambar 9 dan 10)

\section{c.1. Kontektual dengan kawasan setempat}

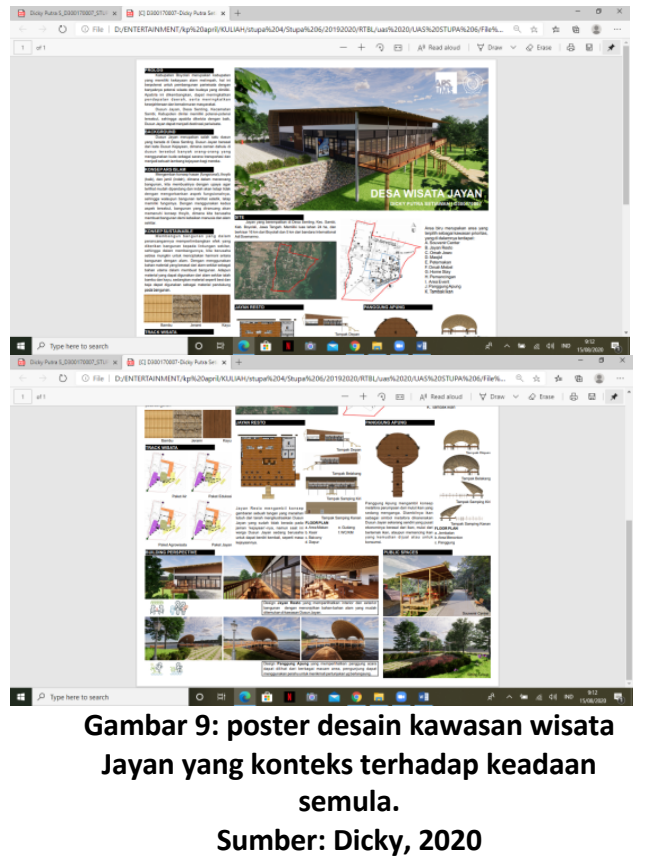

c.2. Konservasi kawasan

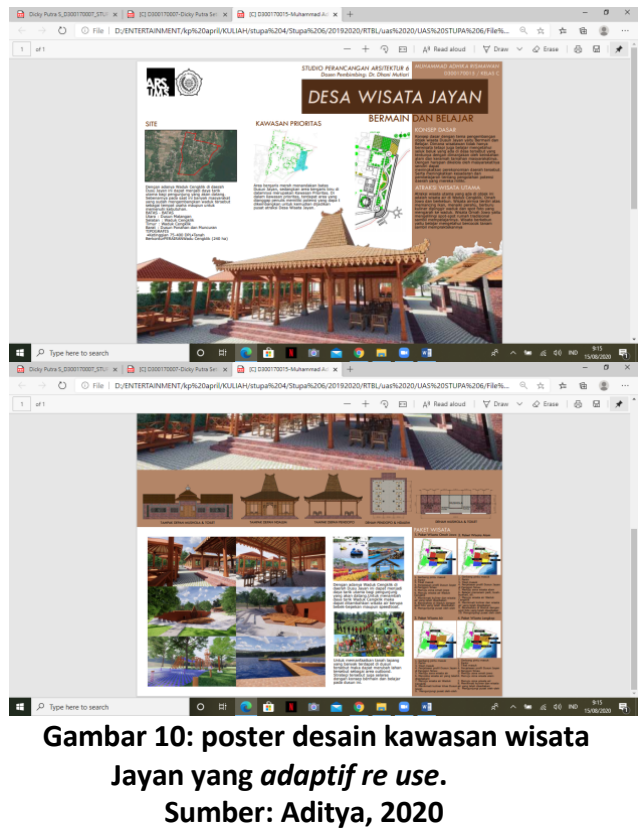

Ketiga proses ini setelah selesai di sosialisasikan kepada masyarakat dalam dalam sebuah pertemuan dengan pemerintah daerah, BPR dan Tokoh masyarakat. Pertemuan dilakukan di Panggon Sinau Dusun Jayan pada tanggal 28 Juni 2020 jam 08.0012.00. (Gambar 11 dan 12) 


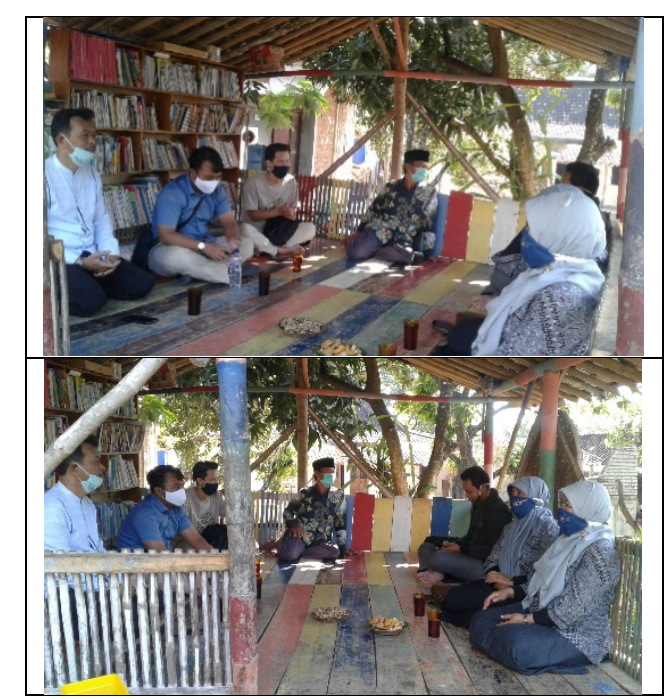

Gambar 11: Pertemuan awal dengan bapak Kepala Desa Senting

Sumber : Dokumen pribadi, 2020

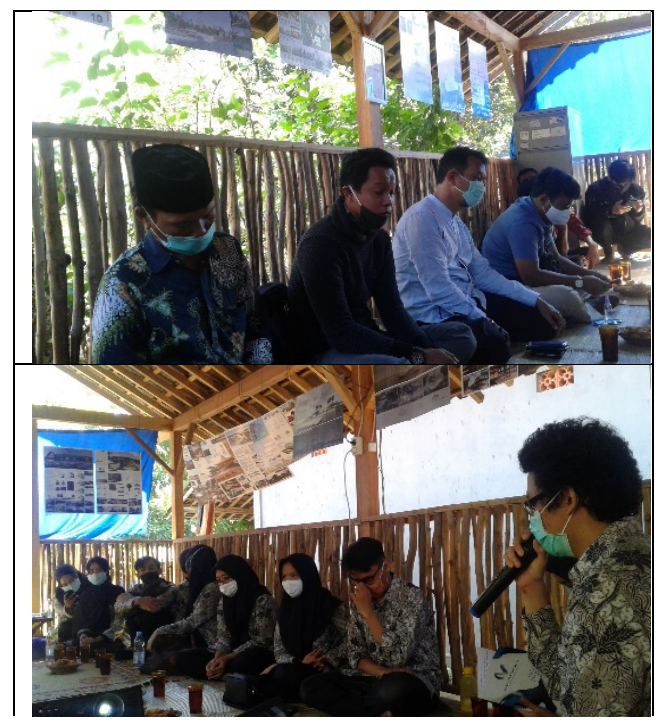

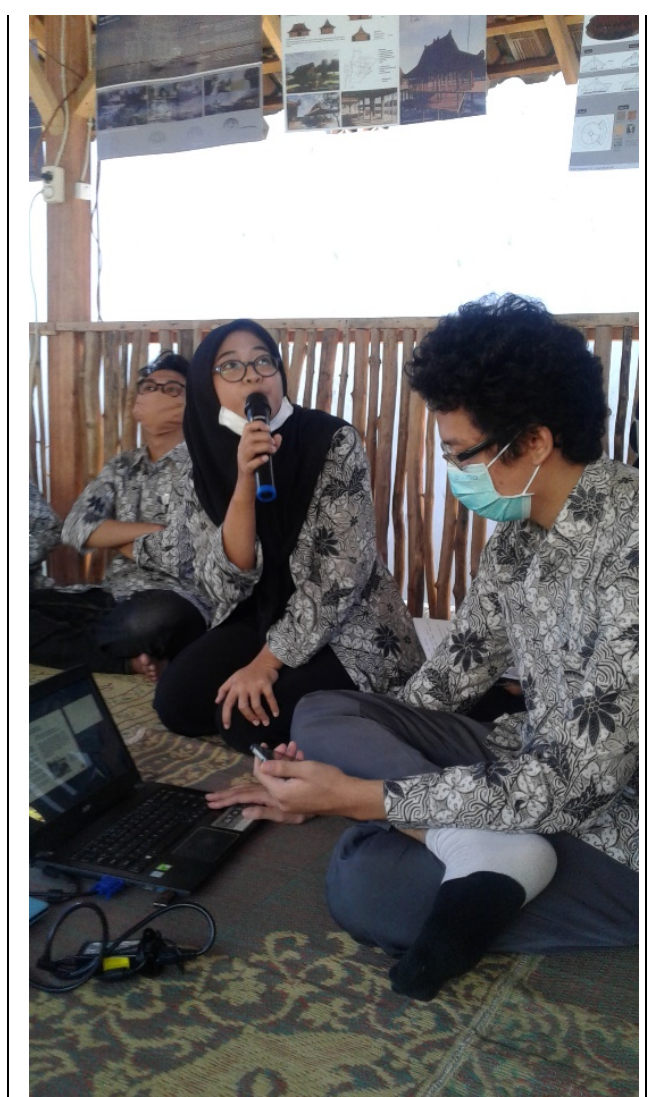

Gambar 12: Presentasi oleh mahasiswa di hadapan masyarakat.

Sumber : Dokumen pribadi,2020

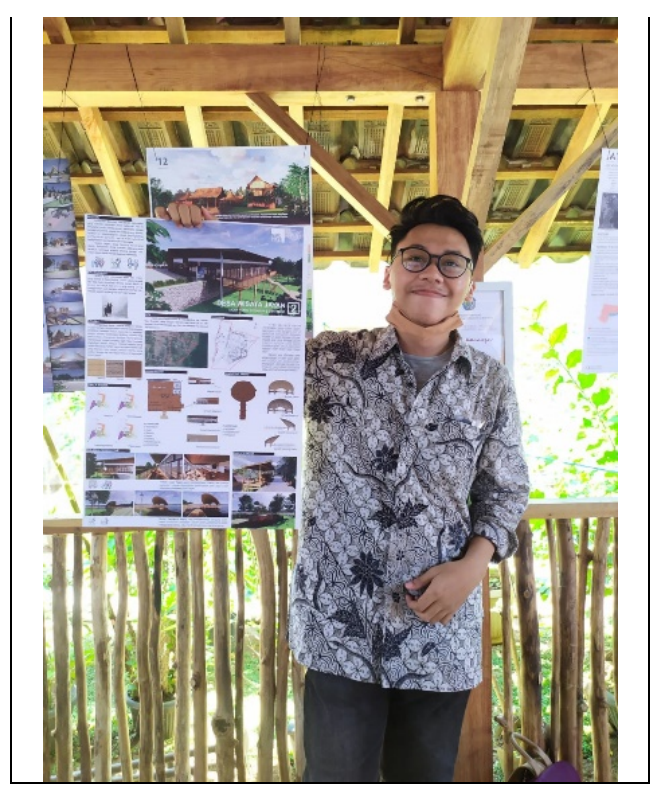




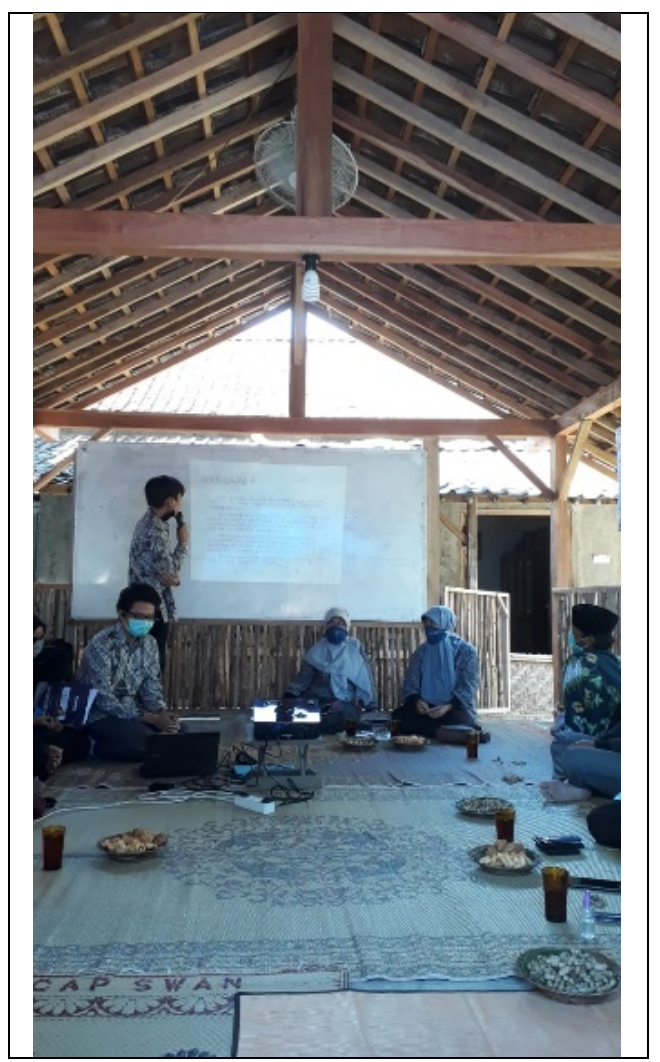

Gambar 13: Presentasi oleh mahasiswa di hadapan masyarakat.

Sumber : Dokumen pribadi,2020

Di akhir acara terdapat pemberian cendera mata dari Fakultas Teknik UMS kepada Bapak Kepala Desa Senting. Harapan dari bapak Kepala Desa ke depannya tidak hanya melaksanakan pendampingan di Dusun Jayan saja tetapi juga dusun-dusun lainnya di Desa Senting (Gambar 14)

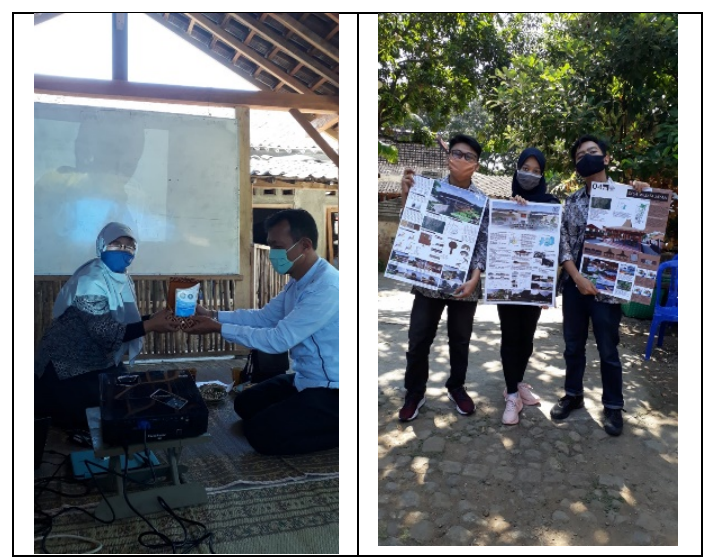

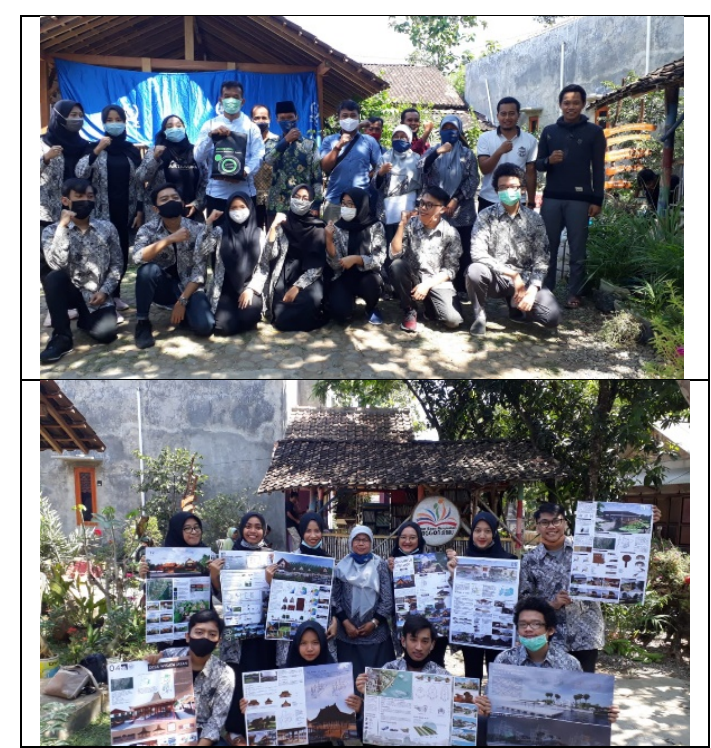

Gambar 14: Acara Penutupan yaitu penyerahan cindera mata dan foto bersama Sumber: Dokumen pribadi,2020

\section{KESIMPULAN}

Hasil dari yang kita presentasikan terdapat beberapa masukan dari bapak Kepala Desa, BPR, dan tokoh masyarakat, bahwa mereka apresiate dengan acara ini dan menilai desain yang lebih dekat dengan kondisi sekarang akan mudah diaplikasikan, sehingga kedepannya diharapkan kita untuk selalu mendampingi proses desain kawasan wisata ini. Selain itu juga diharapkan untuk bisa memberikan masukan juga ke dusun yang lain di Desa Senting.

\section{UCAPAN TERIMA KASIH ATAU PERSANTUNAN,}

Ucapan terima kasih kepada :

1. Kepala Desa Senting

2. Mas Parmin yang selama ini menjadi penghubung kami dengan pemerintahan dan masyarakat di Dusun Jayan.

3. Mas Aris dari IMM Al Gozali Fak, Psikhologi UMS atas segala bantuannya.

4. Seluruh warga Dusun Jayan Desa Senting.

\section{DAFTAR PUSTAKA.}

[1]. Arsitur Studio (2020), 2017, Definisi Urban Planning dan Klasifikasinya, https://www.arsitur.com/2017/

[2]. Dewi Nurhalimah,2020, Pengembangan Wisata Kampung Lukis Sangkrah Sebagai Wisata Edukasi Dan Rekreasi, DP3A program studi Arsitektur FT.UMS. 
[3]. Linch, Kevin, 1987, Good City Form, The MIT Press, London.

[4]. Shirvani, Hamid, 1985, The Urban Design Process, Van Nostrand Reinhold, New York

[5]. Setyadi, Yudi, 2019, Desa Wisata dan Pengembangannya, Ensiclo.com, /2019/10/21/pengertian-desa-wisata

[6]. Trancik ,1986, Finding Lost Space, Theories and Urban Design, John Wiley and Sons. 